\title{
Locomotive Freight Rating and TRAin Resistance.
}

Paper read before the Institution by R. E. KIMBERLEY, Member, on roth December, I920, at Junin, Argentina.

Paper No. 96.

In considering railway efficiency, it is not unfrequent on the part of departmental officers to sacrifice certain benefits to a railway company as a whole on the altar of departmental economy.

It is a regrettable fact that the before-mentioned conditions should exist, also that the comparative statements of statistics of various departments are, at times, only considered separately, and none, or very little, attention paid in combining important factors, and jointly considering the influence of train load and speed on wagon efficiency, and the effect of this efficiency on train speeds and loads, which in their turn directly influence one another.

Thus the traffic officer's neglect to consider the influence of speed on locomotive efficiency in his ambition to obtain a high wagon efficiency on the one hand, or the locomotive engineer's neglect to recognise the effects of slow speed on the earning capacity of wagons on the other hand, may lead to unreasonable demands by either of the departments concerned, and the real efficiency of the railway may be sacrificed for some fancied return, which, although figuring departmentally as good working, may at the same time be the means of an increase in the percentage of working expenses to total receipts.

The existing conditions on British, and some of the European railways, do not call for a serious consideration of locomotive freight rating, inasmuch as the railway companies find it more convenient to run their freight trains over the various sections expeditiously, due, no doubt, to competition and the general demand for quick delivery and also on account of the short leads. 
Consequently, to compare or adopt British methods of railway working with a country like the Argentine would be useless, due to the long leads and difference in local conditions between the two countries, and as is well known in endeavouring to aim at efficiency it is essential to take into consideration all the existing factors and model working regulations to suit existing conditions, rather than blindly adopt methods which, although giving excellent results in one country would, if introduced into another, most probably result in disorganisation with the accompanying expenses.

From a traffic point of view, a maximum return for a minimum train mileage always figures as excellent working, but when this is obtained at the expense of the running department by the overloading of engines, which in its turn may necessitate the changing of engine crews or the planting of trains due to the driver being unable to maintain his scheduled time, it naturally figures against the department as bad working, with the subsequent general disorganisation.

From a locomotive point of view a slow speed and full load means a high freight ton-mileage per engine and a low fuel consumption per ton mile. This, however, reduces wagon efficiency, as heavy loads not only mean slow train movements when running, but may cause delays to more important traffic and increase the difficulty in handling the trains in stations, crossings and such-like; and as wagon efficiency is such an all-important factor in a country like the Argentine, due to the periodical busy seasons which the railway companies have to contend with, the point to be borne in mind is that although the fuel bill is the biggest single item of railway working expenditure, it is not the only criterion of railway efficiency.

In making this statement, the Author does not wish to infer that a high wagon efficiency should be the sole aim of traffic officials when studying matters which concern the running of trains or the rating of locomotives.

In pre-war days the fuel bill of any Argentine railway was extremely high, but due to exorbitant shipping freights at the present time - with very little possibility of them being reduced in the near future-the cost of fuel has increased considerably, and any means by which the consumption of fuel could be reduced should be very carefully considered by the officials concerned.

The reduction in consumption of coal, or its equivalent, at the rate of one kilo. per engine kilometre on a big 
Argentine railway during a good year's traffic would, at the present time, effect an annual saving of anything up to $f \cdot 90,000$.

This is a figure which should not be lost sight of, and every effort should be made to continually remind all the staff concerned that it is imperative for them to minutely watch the fuel consumption with a view to stopping any possible waste or extravagance.

The following diagram No. I shows the relation existing between the total locomotive running expenses and the cost of fuel put on the locomotive tender during the last eight years on the Buenos Aires and Pacific Railway:-

\section{BUENOS AIRES \& PACIFIC AAILWAY COMPANY}

\section{AELATION BETWEEN TOTAL RUNNINC EXPENSES Q COST OF FLEL PUT ON LOCO. TENDEAS.}

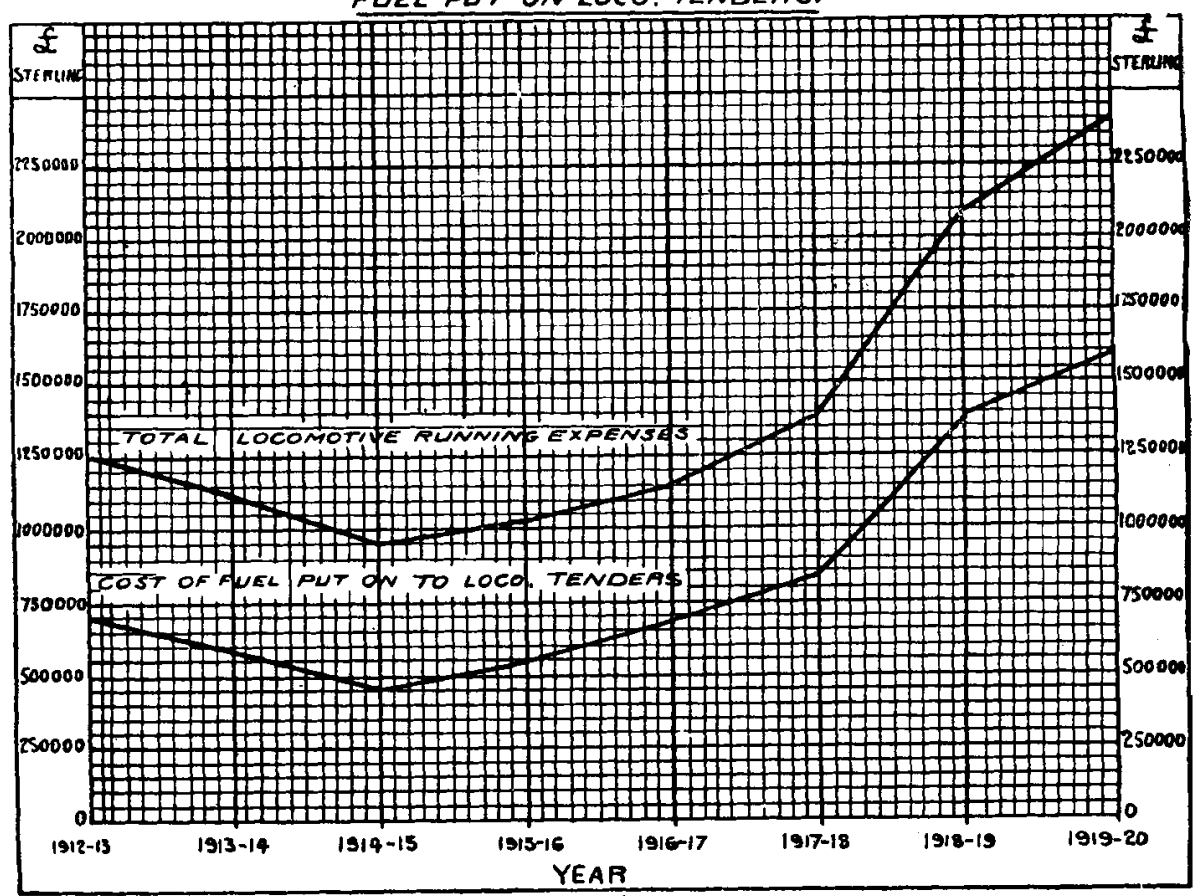

FIG.I.

Accurate engine rating and the ensurance of full engine loads all along the line should be the common aim of traffic and traction officers. 
A glance at the working timetables of the various Argentine railways showing the method by which the different companies compute their train loads, does not, in the Author's opinion, tend to ensure that the locomotives are being properly loaded, and there is, in many cases, no guarantee that the load consigned to certain engines can be hauled over the various sections according to the scheduled time.

The following is an extract from various working timetables, which will give the reader an idea of the different methods adopted in this country for computing train loads:

\section{Buenos Aires and Pacific Railway.}

The loads are computed in "decatoneladas," as follows :-

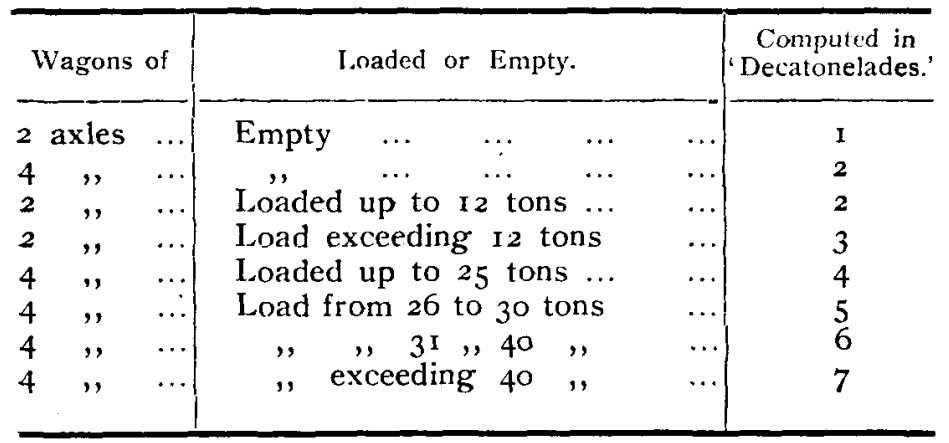

\section{Soutbern Railway.}

The loads are computed in loaded axles, as follows:-

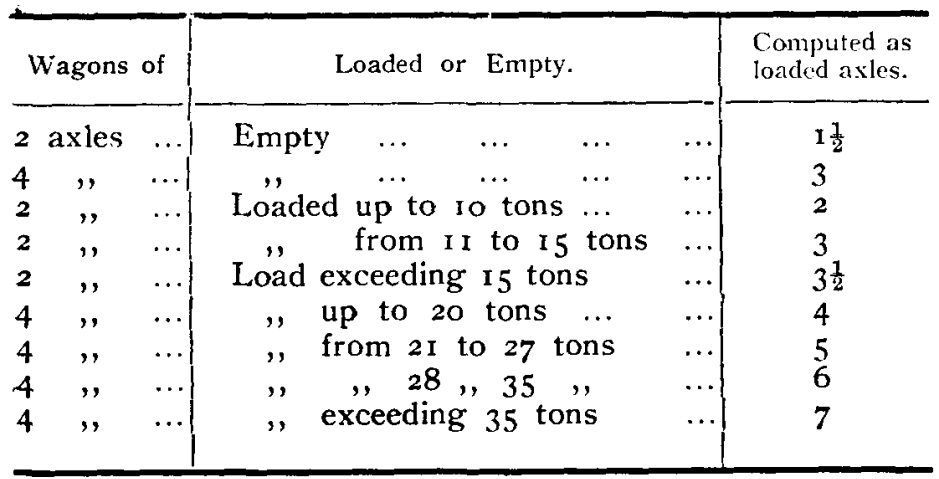

Empty trains, or those carrying more empty wagons 
than loaded, are calculated each five axles empty as four loaded axles.

\section{Central Argentine Railway.}

The loads are computed in tons, and the weight of train is calculated, adding the tare and cargo of each wagon, without taking into consideration the number of axles.

In computing the weight of cattle trains, the tare is taken as the weight of the train.

\section{National Government Line: Central North Argentine Railway.}

The loads are computed in tons and the weight of the train is calculated adding the tare and cargo of each wagon without taking into consideration the number of axles.

\section{Buenos Aires Midland Railway.}

The loads are computed in axles, 120 being the maximum figure, either loaded or empty.

The wagons completely loaded with wheat, coal, sand, bricks and other heavy articles are calculated as being the equivalent of six loaded axles when the weight reaches or exceeds 30 tons.

\section{Central Buenos Aires Railway.}

The loads are computed in tons and the weight of the train is calculated, adding the tare and cargo of each wagon.

The maximum number of axles in a train is as follows:

\begin{tabular}{c|c}
\hline Train with wagons of & Maximum axles in the train. \\
\hline 2 axles. & 140 \\
2 and 4 axles. & 160 \\
4 axles. & 200 \\
\hline
\end{tabular}

\section{Entre Rios Railway.}

The loads are computed in tons and the weight of the train is calculated, adding the tare and cargo of each wagon.

Empty four-axle wagons are calculated as being the equivalent of 5 tons, and those of two axles as eight tons. 
To compute the weight of a train, 500 or more kilos. are considered as one ton, and no allowance is made when the load is less than this figure.

\section{Western Railway.}

The loads are computed in tons, and as the number of wagons comprising a train increases, the total weight of the train is decreased acco- dingly.

\section{Central Cordoba Railway.}

The loads are computed in tons, and a summer and winter load is arranged.

\section{Santa Fe Railway.}

The loads are computed in loaded axles, with a few exceptions.

An allowance is made for the winter working by reducing the loads from $6 \frac{1}{2}$ to 8 per cent.

Three empty axles are calculated as being the equivalent of two loaded axles.

\section{Rosario to Puerto Belgrano Railway.}

The loads are computed in loaded axles as follows :-

\begin{tabular}{|c|c|c|c|c|}
\hline \multicolumn{3}{|c|}{ Wagons of } & Loaded or Empty. & $\begin{array}{l}\text { Computed as } \\
\text { loaded axles. }\end{array}$ \\
\hline & sles & & Empty $\quad \ldots$ & $I_{\frac{1}{2}}^{\frac{1}{2}}$ \\
\hline 4 & , & & $\begin{array}{llll}, & \cdots & \cdots & \cdots\end{array}$ & 3 \\
\hline 2 & ", &.. & Loaded up to ro,ooo kilos. $\ldots$ & $2 \frac{1}{2}$ \\
\hline 2 & $"$, & .. & $\begin{array}{ccccc}\text { from } & \text { Io,oo } & \text { to } & \text { I } 5,000 \\
\text { kilos. } & \ldots & \ldots & \ldots & \ldots\end{array}$ & $3^{\frac{1}{2}}$ \\
\hline 2 & ", & .. & 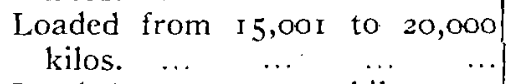 & 4 \\
\hline 4 & " & .. & Loaded up to $2 \mathrm{I}, \infty 0$ a kilos. ... & $5^{\frac{1}{2}}$ \\
\hline 4 & $"$, & 1 & $\begin{array}{ccccc}\text { from } & 2 \mathrm{I}, \mathrm{OO} \text { I } & \text { to } & 28,000 \\
\text { kilos. } & \ldots & \ldots & \ldots & \ldots\end{array}$ & $6 \frac{1}{2}$ \\
\hline 4 & ," & $\cdots$ & 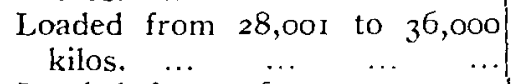 & 7 \\
\hline 4 & ", & ... & $\begin{array}{ccccc}\text { Loaded from } & 36,001 & \text { to } & 40,000 \\
\text { kilos. } & \ldots & \ldots & \ldots & \ldots\end{array}$ & 8 \\
\hline
\end{tabular}

\section{Argentine North=Eastern Railway.}

The loads are computed in tons.

Empty four-axle wagons are calculated as being the equivalent of 15 tons, and those of two axles as 8 tons. 
To compute the weight of a train, $5^{\circ 0}$ or more kilos. are considered as one ton, and no consideration is taken when the load is less than this figure.

It is, of course, understood by all railway men that an engine will not haul the same train weight of empty as loaded wagons, and that train resistance varies not only with the train speed, but also with the average weight of the wagons of which the train is composed.

Notwithstanding this fact, which has been known for years, it has found very little application with a great number of our railways, not only in this country but elsewhere.

As an example: If a certain locomotive could haul 40 fully loaded wagons at a given speed up a specified grade, the wagons carrying a net freight of $\mathrm{I}$, ooo tons and under the same conditions of grade and speed, the engine could haul go empty wagons. But assuming the 40 loaded wagons had a net freight of only 700 tons, the engine would be obviously underloaded. The question is, what number of wagons should be attached to bring the train up to its full engine load:

This subject has been dealt with, to a big extent, by many of the North American railway companies.

Their arrangement, generally known as the equated tonnage system, allows engines to be rated up to their full hauling capacity, in terms of fully loaded wagons. Any variation from the fully loaded wagons is made up by adding on wagons until the pull on the ruling gradient is equal to a train consisting of a full load of fully loaded wagons.

The variation of train resistance, according to the average wagon weight, has received but very little attention, although some of the North American railways, under their adjusted ratings, after taking into consideration the actual weight of a train allotted to a particular type of engine, make certain allowances according to the number of wagons of which the train is composed.

A number of the existing train resistance formulas also fail to take into account the variation of resistance with the wagon weight.

\section{Locomotive Resistance.}

It is not the Author's intention, in dealing with this subject, to go deeply into the various forces and resistances 
connected with the locomotive itself, as this is a subject which would occupy too much space.

The main resistance which opposes the force of steam is usually that caused by the train itself, although at times a big percentage of the indicated power of the cylinders is utilised in moving the engine and tender itself.

The resistances against which a locomotive works are principally comprised of friction. Other resistances occur, however, such as gravity and head and side winds.

Frictional resistances manifest themselves at the flange of the wheels, in the cylinders and steam chests, throughout the motion, in the journal bearings, etc., and although some of them are very difficult to analyse, they all add together to form the total resistance against which the power of the steam is working and have to be deducted from the tractive force available at the cylinders, inasmuch as they reduce the power which would otherwise be available for hauling the train itself.

The only positively useful friction is that created between the tread of the driving wheels and the rails, as this naturally constitutes a resistance to slipping.

Inertia acts as a resistance, due to it absorbing power when accelerating, but as it performs useful work when reclucing speed, there is no necessity to take this into account when considering the power absorbed by the locomotive itself.

The hauling capacity has to be determined from the available tractive force, and although this is information very easily obtainable, it has been included in the Paper in case it may be of use to any of the junior members of the Institution.

The work performed by one piston in a single stroke, in inch-pounds, is

$$
\frac{\text { M.E.P. } \pi d^{2} s}{4}
$$

Where

M.E.P. = the mean effective pressure in pounds per square inch.

$d=$ cylinder diameter.

$s=$ piston stroke. 
Therefore, in one revolution with a two-cylinder simple engine, the work performed will be

$$
\frac{4 \text { M.E.P. } \pi d^{2} s}{4}=\text { M.E.P. } \pi d^{2} s
$$

and as the distance the engine will travel in one revolution of the driving wheels is equal to $\pi \mathrm{D}$, where $\mathrm{D}=$ the diameter of the driving wheels, the only factor required is the mean effective pressure.

This formula will give the indicated tractive force as it is obtained from the mean effective pressure in the cylinders, but of course its full value will never be obtained in practice.

Many different opinions appear to exist as to what percentage of the boiler pressure should be used in calculating the tractive effort of locomotives at slow speeds.

Some authorities in North America consider the maximum available tractive force to be 85 per cent. of the boiler pressure, but in the Author's opinion this percentage is very excessive and scarcely ever obtainable in actual practice.

The only positive manner to obtain the correct percentage would be to examine the indicator cards. As these are not always obtainable, and as a constant figure will be required for the purpose of comparison, 80 per cent. of the b.w.p. will be used throughout this Paper.

On the B.A.P., for the purpose of calculation, 75 per cent. of the working pressure is used as a standard for comparisons; this is quite a liberal allowance, but it does not necessarily follow that trains are not overloaded, even should the mean effective pressure at low speeds be above this figure.

Using 80 per cent. of the b.w.p. will, therefore, give a maximum tractive force at the point of contact with the rails, according to the following equation:-

\section{$.8 \mathrm{P} d^{2} s$}

D

where $\mathrm{P}$ is equal to the boiler working pressure.

In order to prevent slipping it should be remembered that the weight on the drivers must be at least four times as great as the maximum available tractive force.

It is, of course, understood that this tractive effect can only be realised when running at slow speeds, as the capa- 
city of the boiler is limited and has to be considered when the speed of the train is increased.

At times people complain about the condition of the locomotive, especially after she has been out of the shops for some considerable time. In this connection the fact that the tractive effort is calculated on new tyres and new cylinders must not be lost sight of, as any wear which takes place in either the cylinders or tyres naturally increases the available tractive force of the engine.

In studying compound locomotives the formula is slightly more complicated, but if it is assumed that $R$ is the ratio between the area of the two different cylinders in a two-cylinder compound, and assuming the work done by each cylinder to be equal, which constitutes proper working, the back pressure of the high pressure cylinder should be the initial pressure of the low pressure cylinders.

Consequently, if the high pressure cylinder obtained steam at full boiler pressure $P$, and exhausts at a lower pressure $p$, which should represent the initial pressure in the low pressure cylinder, and let $d h=$ diameter of the high pressure cylinder, and $d l=$ the diameter of the low pressure cylinder for equal total pressure.

$$
(\mathrm{P}-p) \frac{\pi d h^{2}}{4}=p \frac{\pi d l^{2}}{4}
$$

but from the definition,

therefore

$$
\mathrm{R}=\frac{\pi d l^{2}}{4} \div \frac{\pi d h^{2}}{4}
$$

and

$$
\frac{\mathrm{P}-p}{p}=\frac{\pi d l^{2}}{4} \div \frac{\pi d h^{2}}{4}=\mathrm{R}
$$

or

$$
\frac{P}{p}-I=R \quad \frac{P}{p}=R+1
$$

$$
p=\frac{\mathrm{P}}{\mathrm{R}+\mathrm{I}}
$$

This infers that the initial pressure in the low pressure cylinder should be equal to the boiler pressure, divided by the ratio of cylinder plus $\mathbf{I}$. 
Therefore, as the figure adopted for the maximum available pressure is $.8 \mathrm{P}$ the equation becomes $p a=.8 \mathrm{P} / \mathrm{R}+\mathrm{I}$ where $p a=$ the mean available pressure on the low pressure piston.

Consequently, for two-cylinder compounds, assuming the work to be equal in both cylinders, the tractive force $=.8 \mathrm{P} d l^{2} s /(\mathrm{R}+\mathrm{I}) \mathrm{D}$, and for four-cylinder compounds the tractive force will be

$$
\mathrm{TF}=\frac{\mathrm{I} .6 \mathrm{P} d l^{2} s}{(\mathrm{R}+\mathrm{I}) \mathrm{D}}
$$

When first considering the rating of the various locomotives on a railway, it appears to be a very simple matter, as it is, in reality, an equation between the power of the engine and the resistance of the train which it has to haul; but the various factors which go to make up the equation are somewhat complex, as apart from a study of the capabilities of the locomotive and its train, the scheduled running time and various conditions of the track, rolling stock and grades have to be taken into account.

The general stumbling block may be expressed by the manner in which most of the Argentine railways have apparently ignored the variation in train resistance, due to variable train composition; this may be seen from the methods in which most Argentine railways have computed their train loads.

There is very little doubt that a reason existed at some time or other which caused the various officers entrusted with this class of work to ignore the previously mentioned variation.

There is no reason, however, at the present time, why it should not be taken into consideration, and if carefully studied considerable improvements would be effected in the running of freight trains, to say nothing of the high efficiency which would result, due to all locomotives along the line being fully, but not overloaded.

With a view to ascertaining exactly what relation existed between train resistance and average wagon weight, the University of Illinois conducted some most interesting experiments some time ago on the Chicago division of the Illinois Central Railway.

The experiments were made over a period of twelve months, and the ordinary freight trains encountered in actual service were selected to insure that the results would represent average railway practice in that district. 
The results obtained from tests with 32 ordinary freight trains conclusively proved that the before-mentioned variation between train resistance and average wagon weight must be taken into account when computing train loads, if accurate engine loads are to be assured.

The total train weights varied between 747 and 2,908 tons; the average wagon weights comprising the various trains were between 16.12 and $69.9^{2}$ tons; the number of wagons of which the trains were composed varied from 26 to 89 , and the track over which the trains ran represented an average of the best North American main line roads, ballasted with broken limestone and equipped with $85 \mathrm{lb}$. rails.

Everything possible was done to ensure accurate results, and the information obtained determines the resistance of freight trains under the usual conditions of operation and the relation existing at any given speed between train resistance and average wagon weight for the purpose of locomotive rating.

A summary of the results of the tests has been reproduced in diagrams Nos. 2 and 3 , which should prove useful to anyone interested in engine rating and train resistance.

The term resistance in the diagrams means the number of pounds of tractive effort required for each ton of the train to keep it in motion on straight and level track at uniform speed in ordinary weather.

In discussing train resistance a question arises as to whether it is necessary to take into consideration the power required to put a goods train into motion.

There is very little doubt that a number of goods trains in this country would not start at all if the total weight of the train had to be instantaneously dealt with by the engine when starting, but due to slack in the couplings trains are generally allowed to start one wagon at a time.

Therefore, as the engines of goods trains do not immediately have to contend with the full load of the train when starting, there is really no necessity to take into account the starting resistance when rating engines.

Sir J. A. F. Aspinall, in describing his experiments, which were conducted to determine starting resistance of trains, obtained a figure of approximately 15 lbs. per ton.

The Master Mechanics' Committees, in their diagram of train resistance, give this value at about $18 \mathrm{lbs}$. per ton. 
THE RELATION BETWEEN RESISTANCE \&

AVERACE CAR WEIGHT AT VARIOUS SPEEOS

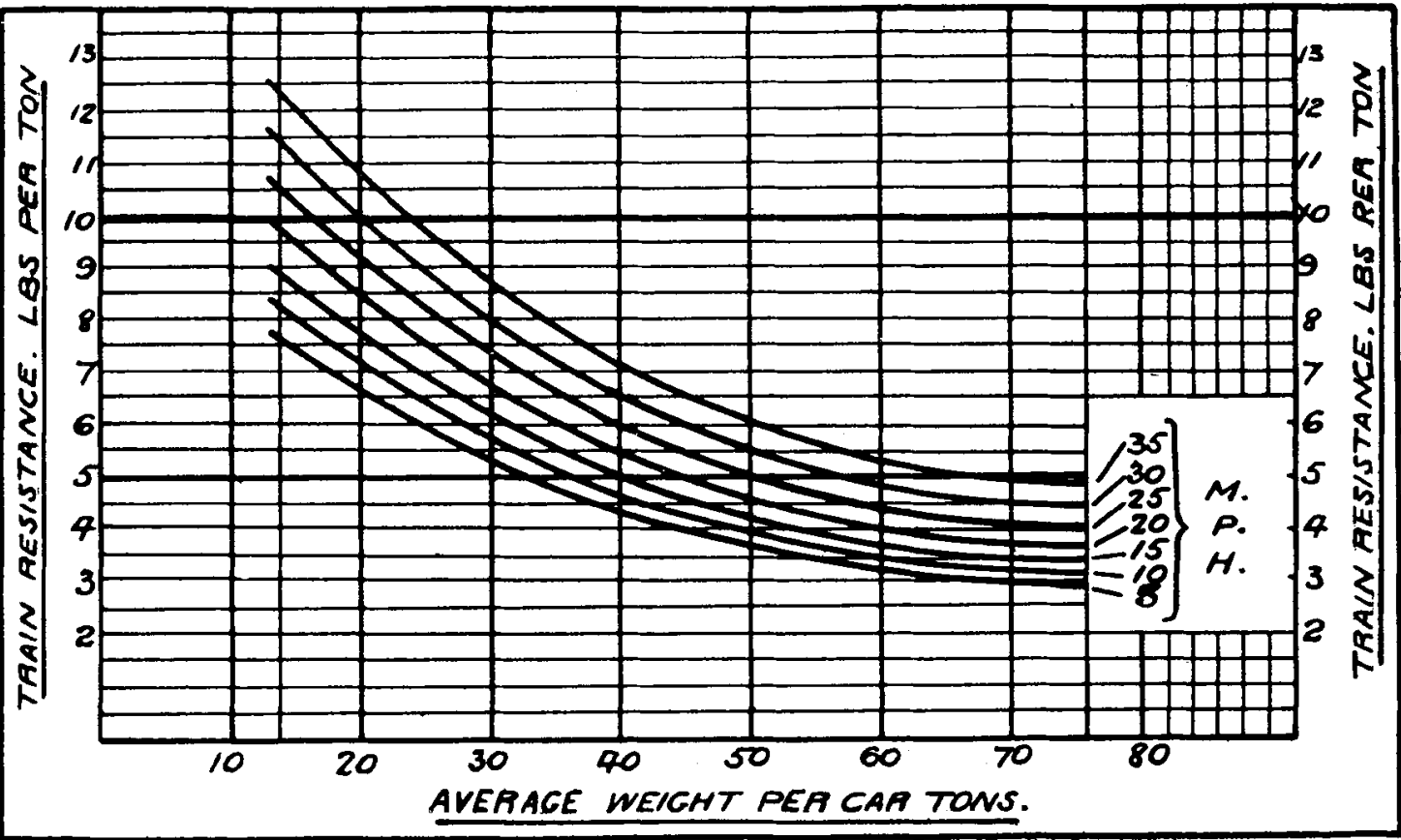

FIG. 2 


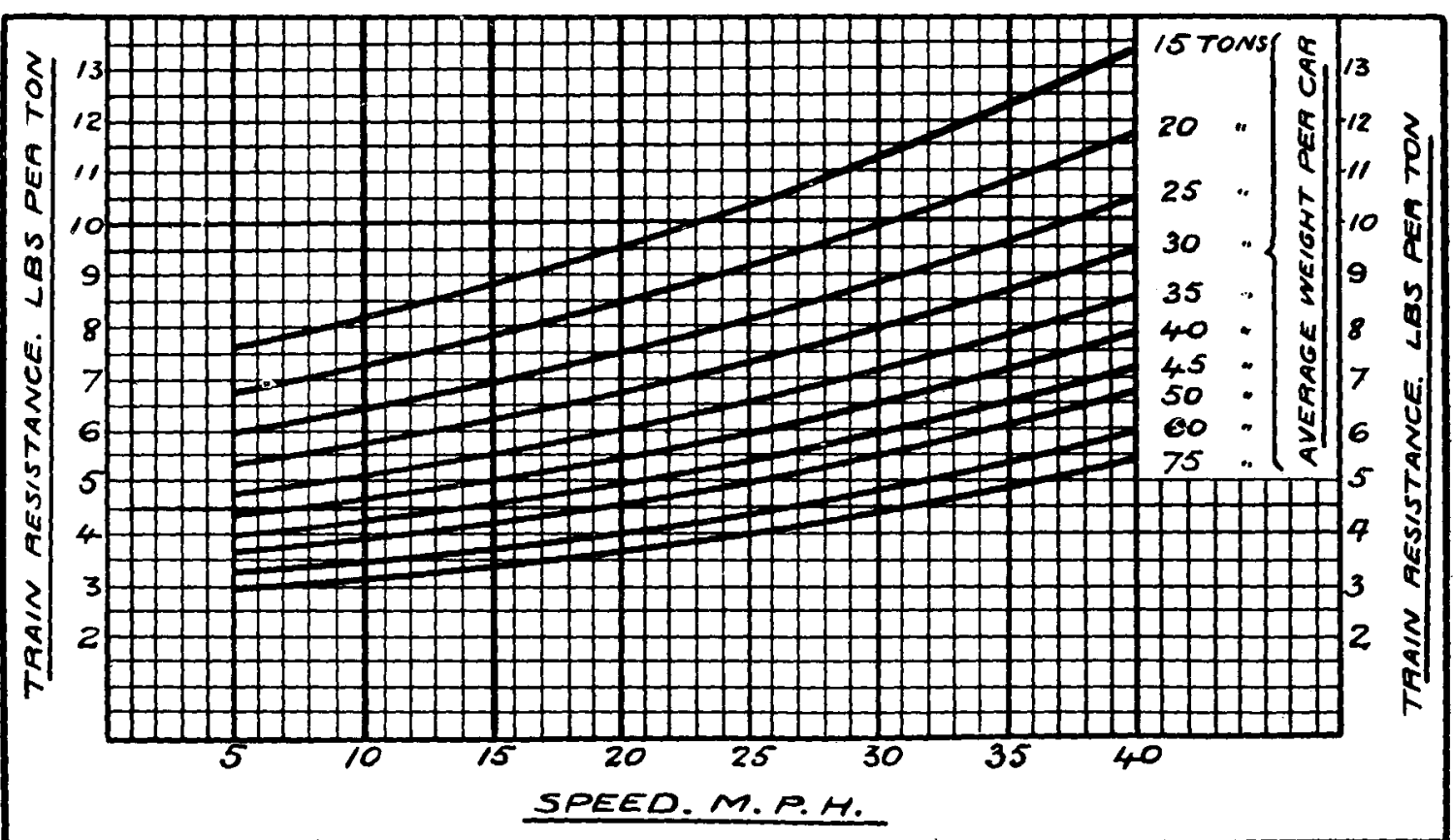

FIG. 3 
Wellington states that from $\mathrm{I}_{4}$ to $\mathrm{I} 8 \mathrm{lbs}$. is required with considerable fluctuations.

Mr. B. A. Worthington indicates 17 lbs. per ton.

Train resistance will now be discussed under the headings of which the various resistances are encountered with a view to ascertain the total train resistance which the locomotive has to contend with as follows:-

I. Speed resistance.

2. Grade resistance.

3. Curve resistance.

4. Wind resistance.

5. Resistance due to composition of train for equal total weights.

(r.) The following formulas, expressed in lbs. per American ton $(2$, ooolbs. $)$, are given for speed resistance by various authorities, and a glance at the diagrams. Nos. 4 and 5 will show the great amount of difference existing between them.

D. K. Clark- $\mathrm{R}=7.2+.0053 \mathrm{~V}^{2}$

A. M. Wellington-

For 20 loaded box cars $\mathrm{R}=4+\frac{\mathrm{V}^{2}}{130}$

For 40 empty box cars $R=6+\frac{V^{2}}{106}$

For 20 loaded flat cars $R=\frac{V^{2}}{I I 3}$

For 40 empty flat cars $R=\frac{V^{2}}{8 I}$

Sir J. A. F. Aspinall-

$$
R=2.25+\frac{V^{\frac{5}{3}}}{5^{6}+.03 L}
$$

where $L=$ length of train in feet over coach bodies.

“Engineering News" suggests $R=2+\frac{V}{4}$

Baldwin Locomotive Works gives $R=3+\frac{V}{6}$ 
speed aesistance clates

N

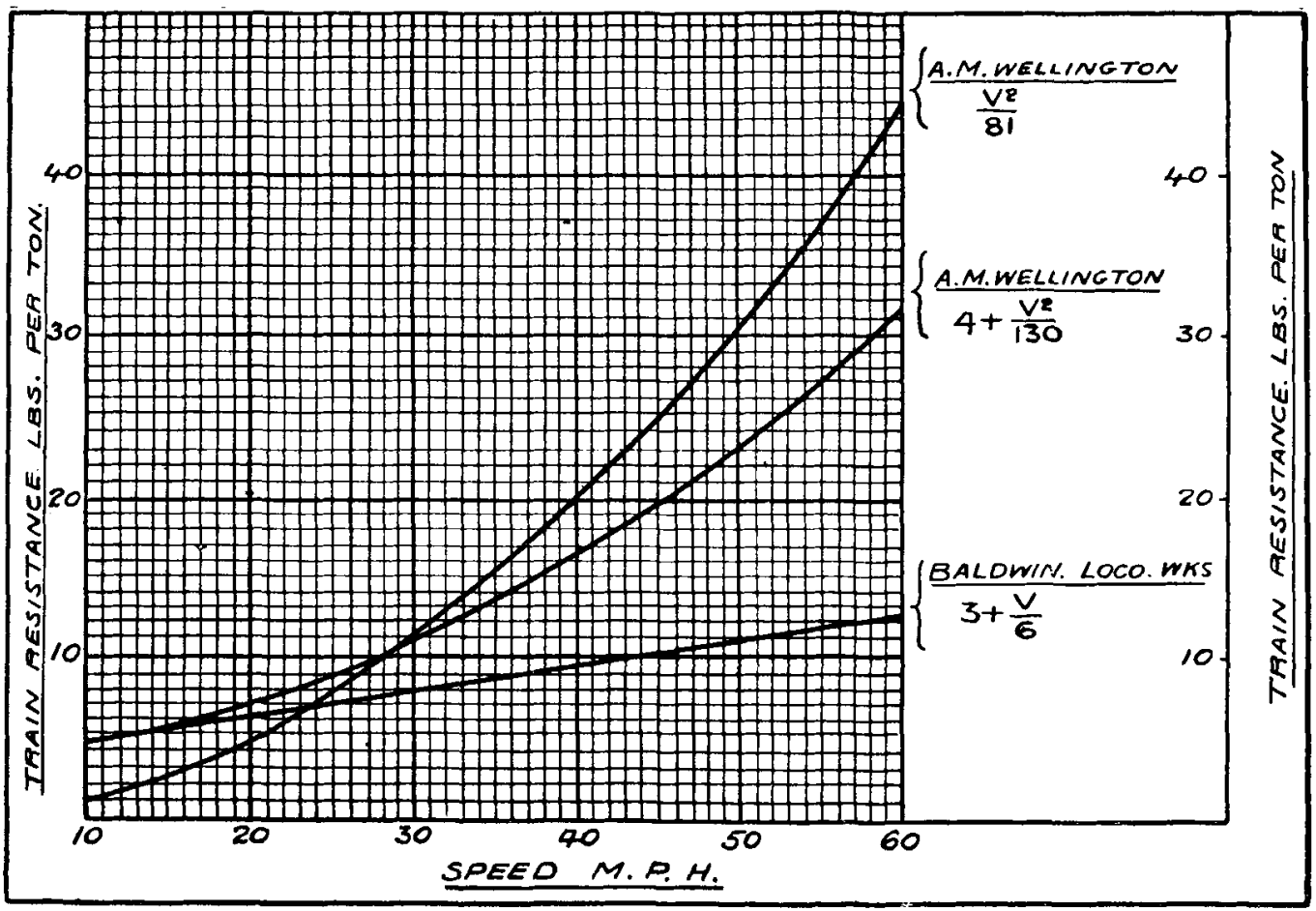

FIG. 4 
sPEEO mEsIstance cuAVES.

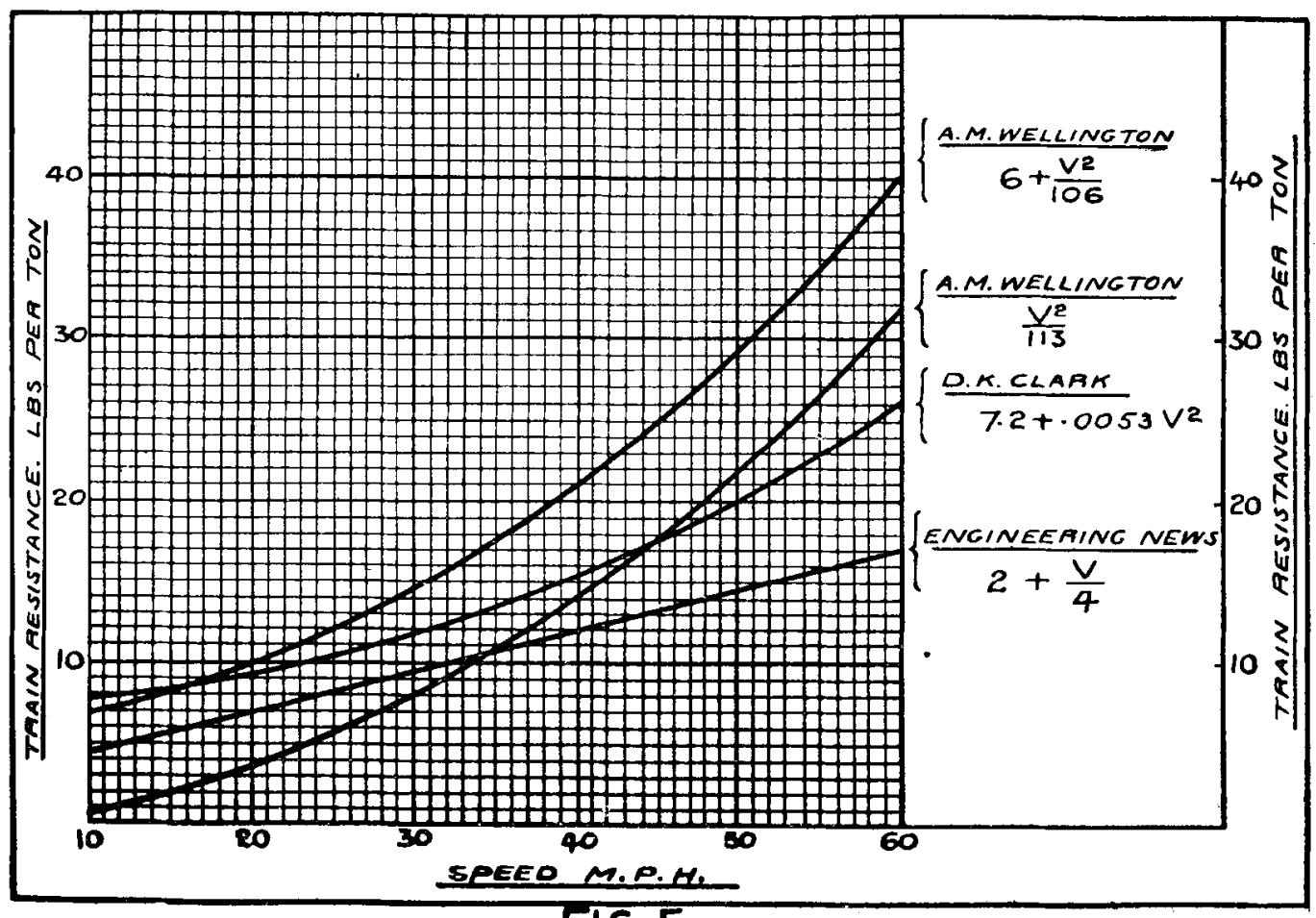

FIC. 5 
It will be noticed that the only allowance made for different composition of trains are the formulas given by Wellington and Aspinall, although, according to the experiments previously mentioned and carried out by the University of Illinois, a great difference exists.

It appears quite logical also that a variation in resistance must take place, according to the number of wagons of which a train of a specified weight is composed.

\section{(2.) Grade Resistance.}

This can be accurately calculated, eliminating the effects of inertia. There is only one value for the power necessary to overcome any specified grade, which is the resistance due to gravity, and when expressed in percentages is as follows :

Let $\mathrm{G}=$ the percentage grade, $\mathrm{R}=$ the resistance in lbs. per ton of 2, ooolbs., then

$$
\mathrm{G}=\frac{m}{5^{280}} \times 100 \text { and } m=\frac{5^{280 G}}{100}
$$

where $m=$ the rise in feet in one mile, divided by the number of feet in one mile, substituting this value, we can write,

$$
\mathrm{R}=\frac{2000}{5280} \times \frac{5^{280 G}}{100}=20 \mathrm{G}
$$

\section{(3.) Curve Resistance.}

The Master Mechanics' Association advocates that curve resistance should be taken as .7lbs. per ton per degree of curvature for wagons and doubled for locomotives.

When curves occur on grades which are at all severe the grades should be compensated by such an amount that the resistance due to both grade and curve will not be greater than the maximum grade on a tangent.

There is a great amount of uncertainty as to what the actual resistance is, due to trains passing round curves.

Wellington stated that it may vary from .33 to even I. 5 pounds per degree, according to actual condition of the track; also the velocity of the train will cause a change in the resistance.

For the purpose of illustrating the total train resistance .7 lbs. per degree of curvature will be used in this Paper. 
230 JOURNAL OF THE INST. OF LOCO. ENGINEERS.

\section{(4.) Wind or Weather Resistance.}

In everyday practice it is noticeable that the weather has a considerable effect on the running of trains.

Some railways have quite elaborate systems for calculating the reductions necessary to compensate for bad weather.

Other lines do not take it into consideration at all, while the B.A. Western, Santa Fé and Central Cordoba Railways alter their winter working time-tables by reducing the loads to be hauled during certain months of the year.

This is a question of such great uncertainty that it would possibly be better for the reduction in train loads to be left to the discretion of the division superintendents, according to the actual state of the weather.

AELATION BETWEEN TAAIN RESISTANCE

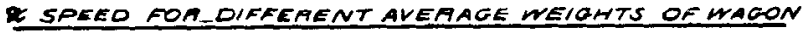

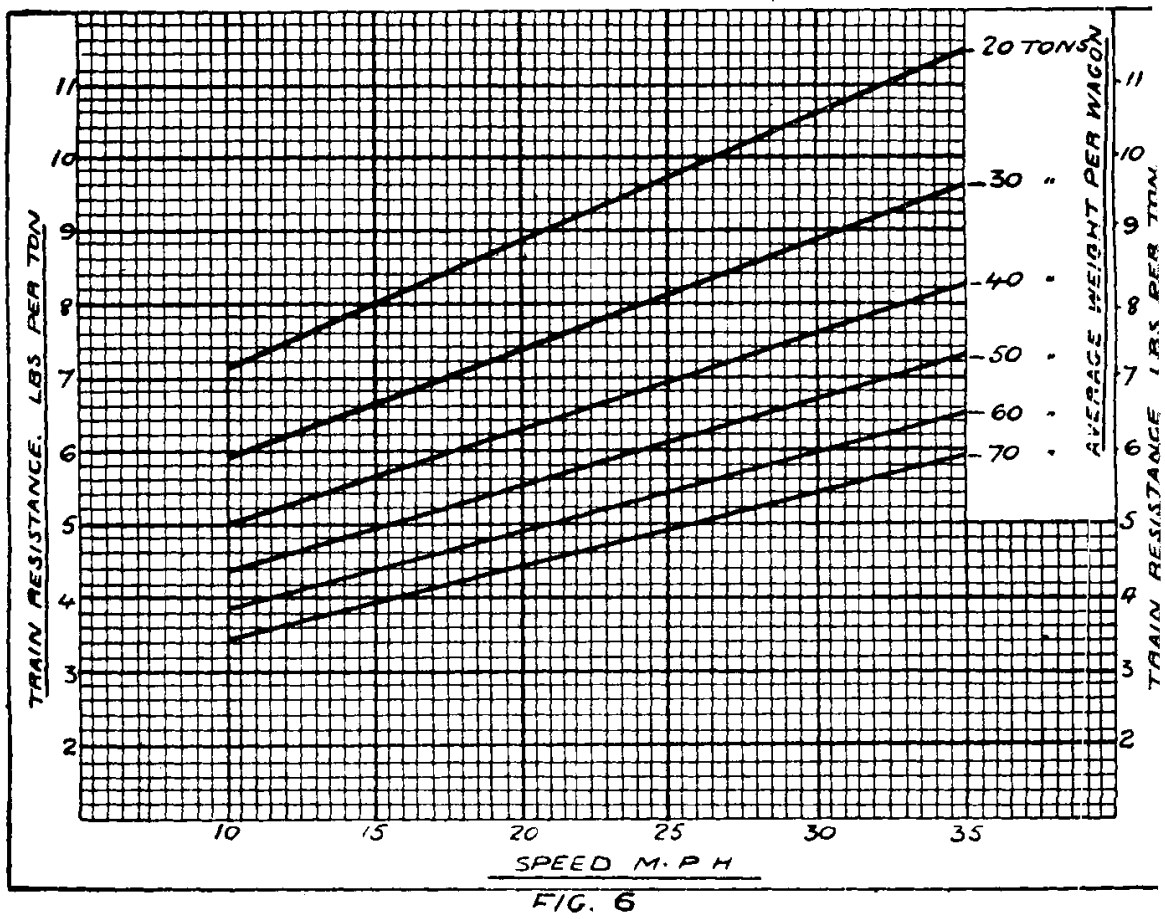


FREIGHT RATING AND TRAIN RESISTANCE-KIMBERLEY. 23I

\section{(5.) Variation in Resistance Due to Composition of Trains.}

Various opinions differ as to what allowance should be made to compensate for trains of equal weights when composed of low capacity vehicles.

A considerable allowance is necessary, according to the results of the I 2 months' tests carried out by the University of Illinois, as shown in diagrams Nos. 2 and 3.

After a study of the prevailing conditions on the Buenos Aires and Pacific Railway, the Author has introduced a formula for calculating the resistance due to the average wagon weight of goods trains, which is shown on diagrams Nos. 6 and 7 .

It will be noticed, by comparing these diagrams with diagrams Nos. 2 and 3 , that the difference in resistance

MELATION DETWEEN TAAIN RESISTANCE

- ArEAAGE WACON WEIGHT AT DIFFEAENT SPEEOS

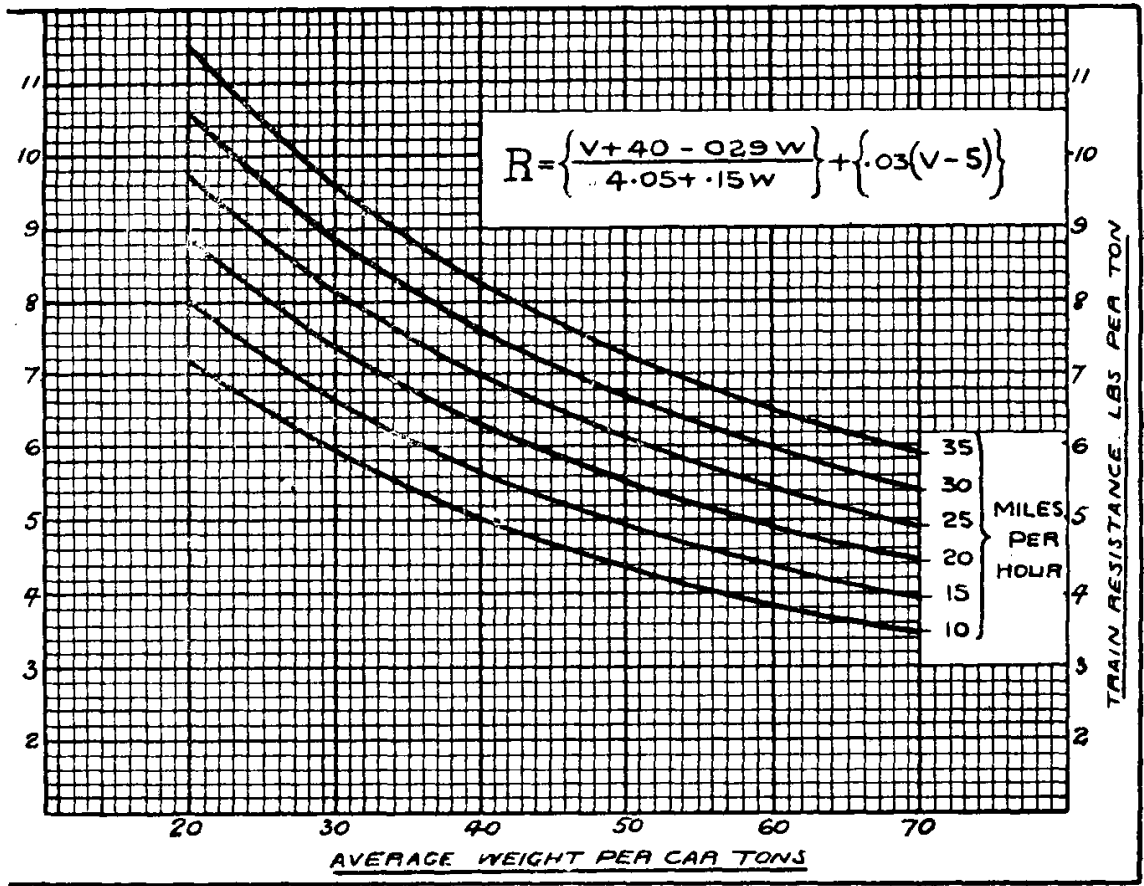

FiG.7 
between low and high capacity wagons is not so great as that allowed by the University of Illinois.

It is not intended to infer that the diagrams are pefectly correct, as to obtain a true result of the actual resistance encountered would necessitate numerous tests with a sensitive dynamometer coach.

On the other hand, it will be found by the use of the diagrams referred to that fairly reasonable results will be obtained in the rating of locomotives, and that a big improvement would be effected by its use in all cases where railway companies have not taken into account the variation in train resistance due to train composition, as in compiling the equation advantage has been taken of the numerous experiments carried out by many different companies.

The following serves to illustrate the results which would accrue by using the before-mentioned diagrams with different composition of trains.

The train will be termed a slow goods, by which is meant a train that is not expected to make more than ten miles per hour up the ruling gradient.

No allowance will be made for inertia as it is assumed the ruling gradient will be long enough to absorb the effect of inertia.

A two-cylinder simple saturated engine will be used of the following proportions:-

Boiler pressure, $175^{1 \mathrm{bs}}$. per square inch.

Diameter of cylinders, I8in.

Stroke of piston, 26in.

Diameter of driving wheels, 67in.

Weight of engine and tender in working order, ro3 tons.

Tractive effort, $.8 \mathrm{P} d^{2} s / \mathrm{D}=176021 \mathrm{bs}$.

Five pounds per ton will be allowed to cover the rolling and journal friction of the engine.

$$
\text { ro } 3 \times 5^{2}=5^{x} 5^{\text {lbs. }}
$$

If it is assumed that the ruling gradient is $4 \frac{1}{2}$ per thousand, which is 45 per cent., the resistance due to grade will be $20 \mathrm{G}$. Consequently, the grade resistance to the engine will be $20 \times .45 \times 103=927$. This added to the rolling and journal friction will be $5^{1} 5+927=1442 \mathrm{lbs}$., and by deducting this from the tractive effort of the engine will give $17602-144^{2}=161601 b s$, available pull at the back of the tender. 
From the diagrams Nos. 6 and 7 it will be noticed that 3.63lbs. per ton is the resistance given for wagons of an average weight of $6_{5}$ tons at a speed of ten miles per hour, and assuming the train is composed of 19 wagons, the total weight of the train will be 1,235 tons.

Consequently, as the .45 per cent. grade will offer a resistance of glbs. per ton, and as $3.63 \mathrm{lbs}$. is the resistance for a train composed of wagons of 65 tons average weight, the total resistance created by a 1,235 ton train, at a speed of ten miles per hour on the ruling gradient, will be $1235 \times(9+3.63)=15,5981 \mathrm{bs}$., and as the pull of the engine at back of the tender is $16,1601 b s$. it will be seen that this engine will handle the train at its specified speed, the velocity on level track being increased accordingly.

Referring to the diagrams Nos. 6 and 7 again, the resistance for wagons of an average weight of 25 tons is given as $6.461 \mathrm{bs}$. per ton.

Therefore, with the same engine, speed and grade, the total number of wagons of 25 tons average weight would be as follows : $16160 /(9+6.45)=1045$ tons weight of train and $1045 / 25=41$ wagons.

For the rating of a fast goods train, which is expected to maintain a schedule of 25 miles per hour up the ruling gradient, the following would be the formula for the same class of engine, assuming the train to be composed of high capacity stock, wagons of 60 tons average weight :-

$$
R=\left\{\frac{V+40-.029 W}{4.05+.15 W}\right\}+\{.03(V-5)\}=5.44 \mathrm{lbs} \text {. }
$$

on level track. Adding glbs. per ton for the grade resistance, the total resistance would be $9+5.44=14.44 \mathrm{lbs}$.

Tractive effort available at back of tender $=16160$, then $16160 / 14.44=1119$ tons, and $1119 / 60=18$ wagons of an average weight of 60 tons each.

It will be seen at a glance, when studying economy in connection with traction and traffic matters, that the results, to say the least, are conflicting.

This fact necessitates the closest co-operation between the two departments concerned, if any real economy is to be effected. The timing of trains should not be decided upon until a complete study of the condition of the road, grades and curves has been carried out in a scientific manner.

On double track, where stations are encountered at 
fairly short intervals and only light grades have to be contended with, the disorganisation, due to bad running, is considerable.

When working single line track with heavy grades and stations at a considerable distance apart, the disorganisation due to one single train being unable to maintain its scheduled time may, and frequently does, upset the working of the whole section, which is accelerated considerably where heavy traffic has to be contended with.

It has been the endeavour of the Author to revive a subject in connection with locomotive engineering, which has apparently been rather neglected for some considerable time, with a view to a more definite understanding being arrived at, as regards the accurate rating of locomotives, rather than laying down any particular course of action as to the manner in which train resistance and locomotive freight rating should be treated.

There is considerable room for improvement, and with the opinions and experiences of various members of the Institution there is no reason why a definite and accurate system of locomotive freight rating should not be arrived at which would be beneficial to the Argentine railways.

\section{DISCUSSION.}

The Chairman : Probably the time of most of us here present is spent doing the routine work incidental to our posts. Mr. Kimberley has taken us out of that side to what, for those who have gone through a technical training, is the more interesting side of our profession. You have had an opportunity of reading Mr. Kimberley's Paper before the meeting; had it been possible to get the printers to produce it sooner the Secretary would have had it in your hands at an earlier date.

The preparation of such a paper as this must have entailed a great amount of work, so that I trust all here present who have anv views on this subject and who have had experience in trials and tests which will contribute to our knowledge of the subject will stand up and take part in the discussion and thereby help to complete the value of the Author's work. At our last meeting a number of members did not get up to speak, because, as they expressed it, they were " afraid of hitting someone higher up" or were "afraid of speaking before the boss." This is a great 
mistake, as the occasion, as in Parliament, is privileged, and it is hoped that all who have anything to say will lay their views before the meeting.

Mr. Bannatyne (Chief Mechanical Engineer, Buenos Aires Western Railway): I wish first of all to congratulate Mr. Kimberley on the subject of his Paper, and on the manner in which he dealt with it. There is no doubt that efficient train loading is one of the most powerful factors in economical transport, and too much attention cannot be paid to it.

In this country in the earlier years of the railways the subject was treated rather in a rough and ready method, due, I have always considered, to a certain extent, to the fact that a very large proportion of the earlier lines were constructed in very flat country, and the size of the trains was governed more by the length of the sidings and other such factors than by the tractive power of the locomotives.

I regret that a little more time has not been allowed to prepare for the Paper, as it covers such a large and interesting ground, but I think that it will be of interest if I give an outline of the system in force on the Buenos Aires Western Railway.

On the Western Railway the system in use for many years was to fix the maximum number of axles that in ordinary practice the engines could handle, three axles of empties being computed as being equal to two loaded, almost all of the wagons being of the two-axle type. When the high-capacity bogie wagons came into use, it was found necessary to compute these of more than the actual number of axles when loaded and an approximate scale was adopted increasing the number of computed axles in accordance with the capacity and the class of load. For instance, the largest wagon, the 45 -ton capacity steel wagon, when loaded with stone, coal, grain (except oats), etc., was computed as of eight axles, with oats as of six, and with wool and all light articles as of four.

As the system outlined above was far from perfect and gave rise in some cases to most uneconomical loading, it was decided to adopt a more scientific method of establishing the true locomotive rating. The want of a dynamometer car was greatly felt, but a temporary apparatus was fixed in a covered wagon which enabled it at any rate to make comparisons between the tractive power of various classes of engines. In the relation of empty to loaded wagons we based our calculations on the factors generally accepted as 
correct, that if for every ton of tare of an empty wagon a rolbs. pull was required, 6lbs. per gross ton was the equivalent for a fully loaded one.

To simplify the work of the station and train staffs it was decided, as practically all our wagon stock was of the high-capacity bogie type and varied very little in tare, to adopt a mean figure which was fixed at 15 tons. It will be easily understood how this simplified the computing of train loads. The line was then divided into groups according to the gradients and the known circumstances that could affect the tractive effort required, and tables formulated for each group and for the classes and types of engine.

In these tables at one end we have the maximum load in tons, and facing it the corresponding number of wagons (of four axles, of course), and at the other end the maximum number of empties with the corresponding total tare in tons. In between come the graduated stages, the number of wagons decreasing one at a time until the maximum is reached, and facing it the corresponding tonnage. It will thus be seen that no matter what combination of loaded and empties has to be taken, the maximum tractive power of the engine will always be employed if enough wagons are available.

I should have mentioned before, when speaking of the: tare of 15 tons, that the actual load carried is always taken in accordance with the waybill. In the case of foreign wagons the actual tare and load are taken, and two-axle wagons are counted as half.

The tables have given excellent results and are still in use, but with various modifications to suit local conditions. In general our endeavour has been to keep them as simple as possible, and they are made on broad lines as we considered the final result would show more economy. If such tables are complicated in practice they are not adhered to as the men concerned do not understand them, or find them too troublesome. As far as possible, frequent changes on the locomotive runs of the maximum loads have been avoided, and though in some sections loss of tonnage may occur, the net result is better as delays are avoided. I give below our table as a sample:- 


\section{PODER DE DAS LOCOMOTORAS. VERANO.}

Tipos : 300 y 800.

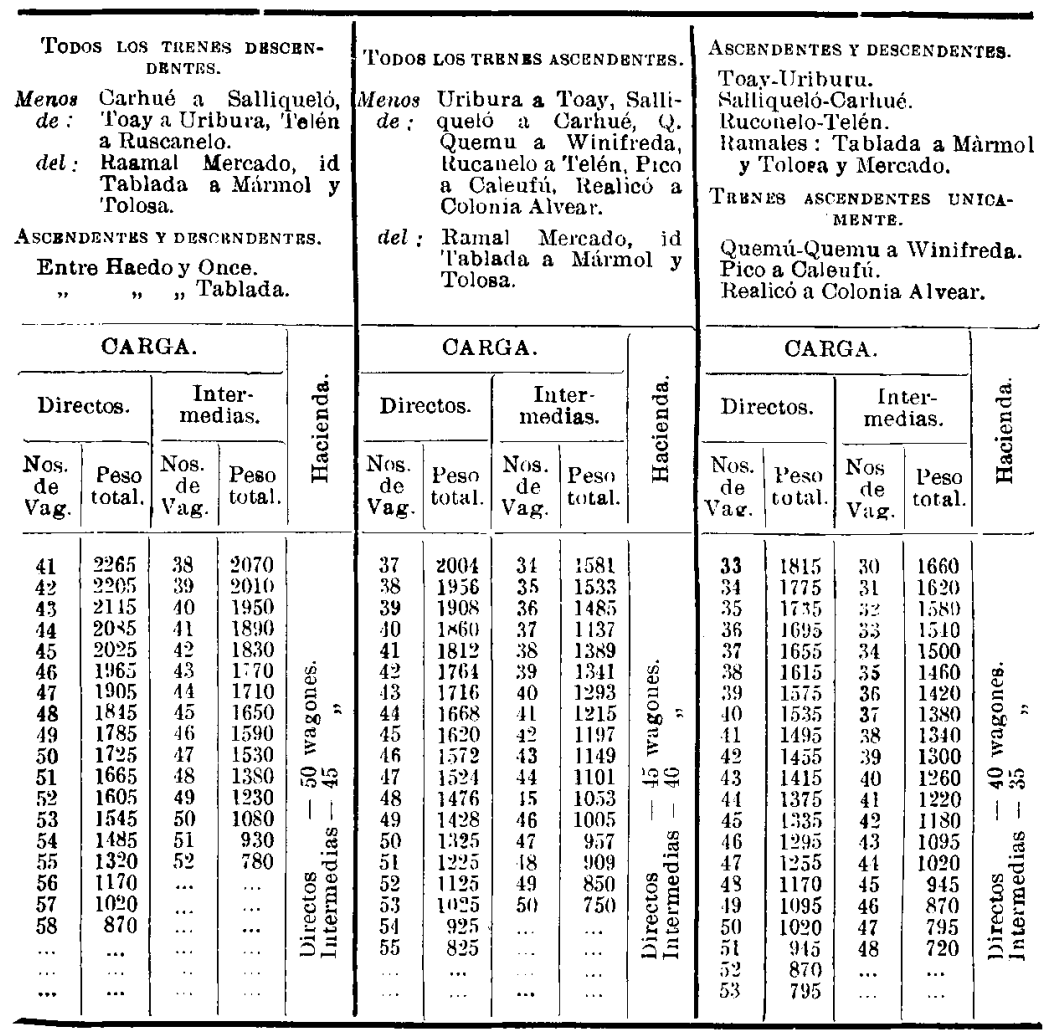




\section{POPER DE LAS LOCOMOTORAS.}

\section{INVIERNO.}

\section{TIPOS I60-I69, I95-200, 201-266, 700-749, 900-9I7.}

\begin{tabular}{|c|c|c|c|c|c|c|c|c|c|c|c|c|c|c|}
\hline \multicolumn{5}{|c|}{$\begin{array}{l}\text { Haedo-Tablada, Mercedes a } \\
\text { Realicó, Ing. Luiggi, Uriburu } \\
\text { o Pico. Ramales : Pehuajó-T. } \\
\text { Lomas, Meridiano } 5^{\circ} \text { La Zanja, } \\
\text { Lincoln-Timote, V. Gomez- } \\
\text { Quemú-Quemu, La Zanja-Sal- } \\
\text { liqueló. }\end{array}$} & \multicolumn{5}{|c|}{$\begin{array}{l}\text { Once a Mercedes. } \\
\text { Ramal : Mescado. } \\
\text { Trus rs Descendentrs. } \\
\text { Rucanelo a Pico. } \\
\text { Caleufú a Pico. } \\
\text { Colonia Alvear a Realicó. } \\
\text { Winifreda a Quemú-Quemu. }\end{array}$} & \multicolumn{5}{|c|}{$\begin{array}{l}\text { Tablada a Marmol y Tolosa- } \\
\text { Triburu a Toay-Salliqueló it } \\
\text { Carhué-Rucanelo a Téén. } \\
\text { TuEx es ascendestre. } \\
\text { Realicó a Colonia Alvear. } \\
\text { Pico a Rucanelo. } \\
\text { Pico a Caleufú. } \\
\text { Quemú-Qucmu a Winifreda. }\end{array}$} \\
\hline \multicolumn{4}{|c|}{ CARGA. } & \multirow{3}{*}{ 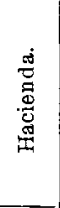 } & \multicolumn{4}{|c|}{ CARGA. } & \multirow{3}{*}{ 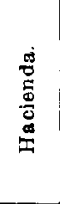 } & & $\mathrm{CA}$ & GA. & & \multirow{3}{*}{ 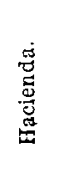 } \\
\hline Dire & tos. & $\underset{\mathrm{m} \theta}{\operatorname{In}}$ & & & \multicolumn{2}{|c|}{ Directos. } & \multicolumn{2}{|c|}{$\begin{array}{l}\text { Inter- } \\
\text { medias. }\end{array}$} & & \multicolumn{2}{|c|}{ Directos. } & \multicolumn{2}{|c|}{$\begin{array}{l}\text { Inter- } \\
\text { medias. }\end{array}$} & \\
\hline $\begin{array}{c}\text { Nos. } \\
\text { de } \\
\text { Vag. }\end{array}$ & $\begin{array}{l}\text { Peso } \\
\text { total. }\end{array}$ & $\begin{array}{c}\text { Nos. } \\
\text { de } \\
\text { Vag. }\end{array}$ & $\begin{array}{l}\text { Peso } \\
\text { total. }\end{array}$ & & $\begin{array}{c}\text { Nos. } \\
\text { de } \\
\text { Vag. }\end{array}$ & $\begin{array}{l}\text { Peso } \\
\text { total. }\end{array}$ & $\begin{array}{c}\text { Nos. } \\
\text { de } \\
\text { Vag. }\end{array}$ & $\begin{array}{l}\text { Peso } \\
\text { total. }\end{array}$ & & $\begin{array}{l}\text { Nos. } \\
\text { de } \\
\text { Vagr. }\end{array}$ & $\begin{array}{l}\text { Peso } \\
\text { total. }\end{array}$ & $\begin{array}{c}\text { Nos. } \\
\text { de } \\
\text { Vag. }\end{array}$ & $\begin{array}{c}\text { Peso } \\
\text { total. }\end{array}$ & \\
\hline $\begin{array}{l}26 \\
27 \\
28 \\
99 \\
30 \\
31 \\
32 \\
33 \\
34 \\
35 \\
36\end{array}$ & $\begin{array}{r}1430 \\
1350 \\
1960 \\
1170 \\
1080 \\
990 \\
900 \\
810 \\
720 \\
630 \\
540\end{array}$ & $\begin{array}{l}24 \\
25 \\
26 \\
27 \\
28 \\
29 \\
30 \\
31 \\
32 \\
33 \\
\ldots\end{array}$ & $\begin{array}{r}1320 \\
1220 \\
1130 \\
1040 \\
950 \\
860 \\
770 \\
680 \\
590 \\
500 \\
\ldots\end{array}$ & 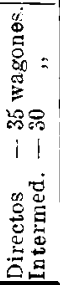 & $\begin{array}{l}24 \\
25 \\
26 \\
27 \\
28 \\
29 \\
30 \\
31 \\
32 \\
33\end{array}$ & $\begin{array}{r}1220 \\
1140 \\
1060 \\
980 \\
900 \\
800 \\
740 \\
660 \\
580 \\
500 \\
. .\end{array}$ & $\begin{array}{l}22 \\
\mathbf{2 3} \\
24 \\
95 \\
26 \\
27 \\
28 \\
29 \\
30 \\
\ldots \\
\ldots\end{array}$ & $\begin{array}{r}1090 \\
1010 \\
930 \\
850 \\
770 \\
690 \\
610 \\
530 \\
450 \\
\ldots \\
\ldots\end{array}$ & 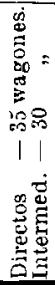 & $\begin{array}{l}20 \\
21 \\
29 \\
23 \\
24 \\
25 \\
26 \\
97 \\
28 \\
29 \\
30\end{array}$ & $\begin{array}{r}1100 \\
1080 \\
1010 \\
940 \\
870 \\
800 \\
730 \\
660 \\
590 \\
520 \\
450\end{array}$ & $\begin{array}{l}18 \\
19 \\
20 \\
21 \\
22 \\
23 \\
24 \\
25 \\
26 \\
27 \\
\ldots\end{array}$ & $\begin{array}{l}990 \\
965 \\
895 \\
895 \\
755 \\
685 \\
615 \\
545 \\
475 \\
405 \\
\ldots\end{array}$ & 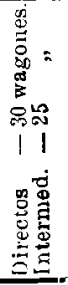 \\
\hline
\end{tabular}

Tipos 600-639 y 695-699.

\begin{tabular}{|c|c|c|c|c|c|c|c|c|c|c|c|c|c|c|}
\hline \multicolumn{5}{|c|}{ 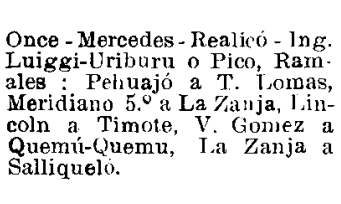 } & \multicolumn{5}{|c|}{$\begin{array}{l}\text { Ramal : Mercado. } \\
\text { TrRn es Descendentas. } \\
\text { Rucanelo a Pico. } \\
\text { Caleufú a Pico. } \\
\text { Colonia Alvear Realicó. } \\
\text { Winifreda a Quemú-Quem. }\end{array}$} & \multicolumn{5}{|c|}{$\begin{array}{l}\text { Tablada a Mirmol Y Toloso } \\
\text { Uriburu a Toay, Sahiquelo a } \\
\text { Carhué-Rucanelo a Telen. } \\
\text { Trun } \Delta \text { sscrndentes. } \\
\text { Realicó a Colomia Alvear. } \\
\text { Pico a Rucanelo. } \\
\text { Pico a Caleufú. } \\
\text { Quemú-Quemu a Winifreda. }\end{array}$} \\
\hline \multicolumn{4}{|c|}{ CARGA. } & \multirow{3}{*}{ 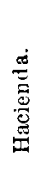 } & \multicolumn{4}{|c|}{ CARGA. } & \multirow{3}{*}{ 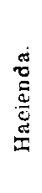 } & \multicolumn{4}{|c|}{ CARGA. } & \multirow{3}{*}{ 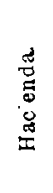 } \\
\hline \multicolumn{2}{|c|}{ Directos. } & \multicolumn{2}{|c|}{$\begin{array}{l}\text { Inter- } \\
\text { merliass }\end{array}$} & & \multicolumn{2}{|c|}{ Directos. } & \multicolumn{2}{|c|}{$\begin{array}{l}\text { Inter- } \\
\text { medias. }\end{array}$} & & \multicolumn{2}{|c|}{ Directos. } & \multicolumn{2}{|c|}{$\begin{array}{l}\text { Inter- } \\
\text { medias. }\end{array}$} & \\
\hline $\begin{array}{c}\text { Nos. } \\
\text { de } \\
\text { Vag. }\end{array}$ & $\begin{array}{l}\text { l'eso } \\
\text { total. }\end{array}$ & $\begin{array}{c}\text { Nons. } \\
\text { de } \\
\text { Vag. }\end{array}$ & $\begin{array}{l}\text { l'eso } \\
\text { total. }\end{array}$ & & $\begin{array}{c}\text { Nos. } \\
\text { de } \\
\text { Vag. }\end{array}$ & $\begin{array}{l}\text { Pes } \\
\text { total }\end{array}$ & $\begin{array}{l}\text { Nus. } \\
\text { de } \\
\text { Vay. }\end{array}$ & $\begin{array}{l}\text { Peso } \\
\text { total }\end{array}$ & & $\begin{array}{l}\text { Nos. } \\
\text { de } \\
\text { Vag. }\end{array}$ & $\begin{array}{l}\text { Peso } \\
\text { total. }\end{array}$ & $\begin{array}{l}\text { Nos. } \\
\text { de } \\
\text { Vag. }\end{array}$ & $\begin{array}{l}\text { Peso } \\
\text { total. }\end{array}$ & \\
\hline & 1000 & & & & & & & & & & & & 1310 & \\
\hline 36 & 1810 & 33 & 1710 & : & 33 & & 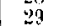 & & $\Xi$ & 29 & 1470 & 2 & 1240 & $\stackrel{乛}{\Xi}$ \\
\hline 37 & 1720 & 34 & $16 \div 0$ & 8 & 34 & 10 & 30 & 14 & & 30 & 1400 & 2 & 1170 & $D_{t !}=$ \\
\hline 3 & $\mathbf{j} 630$ & 35 & $15 \div 0$ & 00 & 35 & 1520 & 31 & & & 31 & 13.30 & & 1100 & 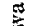 \\
\hline 39 & 1540 & 36 & 1440 & $E$ & 36 & 4 & 39 & 12 & in & $3 \mathfrak{Z}$ & 1260 & & 1030 & \\
\hline 40 & 1450 & 37 & 1350 & 129 & 37 & 1360 & 33 & 11 & 1990 & 33 & 1190 & 30 & 960 & हैं \\
\hline 41 & 136 & 38 & 1960 & & 38 & & 34 & & 1 & 34 & 1120 & 31 & 840 & 11 \\
\hline 42 & 12 & 39 & 1170 & & 39 & & ? & 10 & & 35 & 1050 & 3 & 820 & \\
\hline 43 & 1180 & 40 & 1080 & वं & 40 & 11 & 30 & 92 & & 36 & 98 & & 750 & $\dot{0}$ \\
\hline 44 & 1090 & 41 & $9 ! 90$ & $\stackrel{g}{\Xi}$ & 41 & 1010 & 37 & 84 & & 37 & $\$ 10$ & 3 & 680 & $\stackrel{\text { g }}{g}$ \\
\hline 45 & 1000 & 42 & 80 & & 42 & 96 & 38 & 76 & D. & 38 & 840 & 3 & 610 & 苛 \\
\hline If & 91 & 43 & 810 & & 43 & 8 & 39 & 68 & & 39 & 78 & 36 & 540 & $\stackrel{\leftrightarrow}{=}$ \\
\hline 47 & 820 & 44 & 720 & & 44 & 800 & 40 & 600 & & 40 & 700 & & $\cdots$ & $\hat{A} \Xi$ \\
\hline
\end{tabular}


The Chairman : Mr. Sedgfield, who is an enthusiastic supporter of the Institute, apologises for not being able to attend this meeting. He has sent some notes which I will ask the Secretary to read.

Mr. Sedgfield (Chief Mechanical Engineer, Central Uruguay Railway): The Author has selected as his subject one which must be of perennial interest to all those concerned with train movement on a railway, and in view of the everincreasing cost of fuel the efficiency of locomotive working, either from the point of view of the machine itself as the medium for converting stored energy into useful work, or its handling under service conditions in such manner that its capabilities are put to the best possible use, are matters of supreme importance. It may be noted, however, from diagram No. I accompanying the Paper that the total running expenses on the Pacific Railway have advanced during the last three years in greater ratio than the cost of fuel, which points to other items involved having grown as well.

Coming to the main purpose of the Author, viz., the establishment of some uniform method of freight rating, we find great stress laid on the variable resistance to traction offered by wagons of different gross weights, and the suggestion that this must form a determining factor in establishing engine loads. He directs attention to the little consideration generally bestowed on this fact, but it must be borne in mind that there are few countries in the world where railways can be so uniformly level as in the continentwide dead level Pampas of the Argentine, and that the moment real gradients are encountered gravitational resistances outweigh all others. Under such conditions the fact that frictional resistance of rolling stock may be 4 or 7 lbs. per ton is often a matter of only relative importance.

Nevertheless, the peculiar topography of the Argentine Railways doubtless offers a field for all possible consideration being bestowed on this point, and it is obviously an argument in favour of the high-capacity wagon if (and the "if", is often a large one) such stock can be, even in the main, loaded to its full gross weight capacity. The Paper does not offer any suggested method of giving the factor in question a direct bearing on the make-up of engine loads, and I am not sufficiently conversant with conditions in the Argentine to appreciate what difficulties may exist, but as presumably freight trains are often composed of stock of greatly varying capacities, the estimation of the frictional resistance to a point at which the tractive power of the locomotive would balance it, might conceivably involve more 
calculation than could be expected of the average traffic agent, even when assisted by tabulated data, because it would be necessary to consider at times each vehicle in its fully, or partly loaded, or empty state.

The present methods of computing loads as cited by the Author for various railways show considerable divergency of practice, and I am quite in accord that the axle as a unit leaves much to be desired. For the particular railway with which I am connected the traction clepartment requires train loads to be dealt with in terms of gross tonnagre, and traffic officials are provided with the fullest information enabling them to compile schedules suited to the capacities of all classes of engines at a variety of mean through speeds. The line, however, is of a sinuous and undulating character with ruling gradients of 16 per 1,000 , say 1 in 62, and it may prove instructive to note the effect of this on locomotive haulage capacity by making a comparison with the example worked out in the Paper. Take an actual engine of the following dimensions :-

\begin{tabular}{|c|c|c|c|c|}
\hline Boiler pressure & & & & I 60 lbs. \\
\hline Cylinders & $\cdots$ & & & $18 \mathrm{in} . \times 24 \mathrm{in}$. \\
\hline $\begin{array}{l}\text { Driving wheels } \\
\text { Weight of engine }\end{array}$ & & $\begin{array}{l}\ldots \\
\text { tender }\end{array}$ & in & 6oin. diam. \\
\hline
\end{tabular}

The tractive effort at 85 per cent. of the boiler pressure, which does not result in practice in the loads assigned to the engine proving excessive, gives 17,625 lbs. or a total practically equal to that in the Paper. The resistances are calculated as follows:-

Coupled wheels 34.5 tons at $25 \mathrm{lbs} . \ldots=862 \mathrm{lbs}$.

Frictional resistance of bogie and $\frac{2}{3}$ weight of tender 30.8 tons at $4 \mathrm{lbs} . \ldots \quad \ldots=\mathrm{l} 23 \mathrm{lbs}$.

Gravitational resistance on gradient of

$$
\mathrm{I} \text { in } 60=36.6 \mathrm{lbs} . \times 65.3 \text { tons } \ldots=\frac{239 \mathrm{llbs} .}{3376 \mathrm{lbs} .}
$$

Deducting this from the tractive effort of $17,625 \mathrm{lbs}$, there remains an available pull behind the tender of $14,249 \mathrm{lbs}$.

The frictional resistance of rolling stock is taken at 7 lbs. so that on the gradient in question the engine capacity is $14249 / 7+36.6=327$ tons, as against the $1,2.35$ tons quoted by the Author for an engine of similar tractive power on what he apparently considers the ruling gradient in the Argentine of $4 \frac{1}{2}$ per 1,000 , say I in 222 . It will thus be 
noted that frictional resistance of rolling stock in such circumstances forms less than $1 / 6$ th of the total, and in the case cited its reduction from, say, 7 to 4 lbs. would only result in an increased haulage capacity of 24 tons.

The allowance of only 5 lbs. per ton resistance for the B.A.P. engine seems inadequate to cover all frictional losses in the machinery, and the $3.6_{3} \mathrm{lbs}$. train resistance is for uniformly high-capacity stock. With a more mixed load the engine's capacity would be less.

It appears, however, that engines of equal power may haul from three to four times the load on Argentine lines compared with the Central Uruguay Railway which should have a marked effect on the cost of haulage. It is nevertheless a fact that hitherto freight rates on the Central Uruguay Railway have been substantially lower than in the Argentina, and if fat dividends have not been earned we manage to pay our way, and by comparison it would seem the Argentine lines should be veritable gold mines. If the discrepancy is attributable only in part to engine power not being used to full advantage, the Author, by calling attention to the matter, may have rendered a valuable service.

Mr. N. H. Brierley (Assistant Locomotive Running Supt. B.A. Gt. Southern Railway) : This is a very important question, and I am particularly glad it has come up for discussion at the present time as we on the Southern Railway may be considered to be in the throes of our second birth in this respect.

Some eight years ago we instituted the system of engine rating by calculated axles; by this system wagons were marked on their label with the number of axles which they were to count in favour of the engine. The calculated axle was taken at 8 tons and the computation number rose in accordance with the load contained in a loaded wagon up to a maximum of seven for a fully loaded 40 or 45 -tom capacity wagon.

This gave rise to serious overloading of the engine in the case of trains composed of high-capacity stock and loaded to their full capacity as a 4.5-ton capacity wagon with 16-ton tare totalled the equivalent of $7 \frac{1}{2}$ calculated axles even when the capacity limit was not exceeded.

With one class of traffic, namely, potatoes, we frequently got cases of wagons loaded up to 48 tons instead of 45 , and in these cases there was an under-calculation of 14 per cent. Difficulties of this nature forced us to try a new 
scheme, and we are now getting out a straight tonnage rating.

Mr. Bannatyne in his remarks stated that they had adopted a sliding scale of load in accordance with the number of wagons composing the train. As far as I gather, the total tonnage haulable was reduced by 60 tons for each wagon in excess of the minimum number of wagons which could carry the maximum total engine rating.

It is this point which at present is our chief stumbling block, and we are hunting for a satisfactory sliding scale which will decrease the permissible total load as the length of train increases. We have tried to simplify the problem by limiting the maximum permissible tare to half the haulage power of the engine, but we found that this did not cover the case.

We are now working on a sliding scale similar to that in use on the Western Railway but based on axles instead of wagons, and we have decided to adopt a reduction figure of 9 tons in total permissible gross load for each axle added over and above the minimum number of axles which can accommodate the maximum gross load permitted for each class of engine on each stretch of road.

Mr. Sedgfield's remarks to the effect that we in Argentina, with our long stretches of open level country, ought to be able to do great things in the way of economical operation, loses sight of the very considerable effect that even moderate winds can have on train operation in an open country. I note that the Western Railway have found it necessary to make separate tables for winter and summer, and it is to my mind essential for the success of the tonnage rating of locomotives that some such provision should be made.

Mr. Johnson (Chief Storekeeper, Central Argentine Railway): I should first like to thank Mr. Kimberley for his Paper, which deals with a subject to which, perhaps, insufficient attention has been paid in the past.

Amongst the various lines operating in this country to-day there are many different practices reigning as regards the rating of freight locomotives, and to a large extent the old-fashioned system of calculating the power of an engine by the number of axles it can haul at a given speed over the ruling grade of the various runs still prevails, modified by an intricate method of adjusting the axles of high-capacity stock-both in the case of empty and loaded-to make them assimilate, more or less, to the lower capacity of older types 
of stock. But even with these intricate modifications, the actual weight behind the engine, that is, the drawbar pull, is not defined.

This was so much so in the case of the Central Argentine Railway that thirteen years ago it was decided to abolish it, and put in its place a system worked out on the actual weight behind the engine. It was my pleasure to be encharged with the task of evolving the most simple method of introducing such a system of tonnage loading as would bring it within the comprehension of the working staff of the line.

The necessity for the change can, perhaps, best be illustrated by a short review of what was the situation as regards anomalies under the axle method of rating.

For purposes of train formation three empty axles were considered the equivalent of two loaded axles, and in this respect no consideration whatever was given as to the tare weight of the vehicles nor whether the axles were bogies or rigid. For instance, take two engines of a similar class, each rated with a power of 200 axles between two given points ; the train of first engine might be composed of empties made up of I 8-ton platform wagons with two two-axle bogies each and with a tare weight per wagon of eight tons. To fully load this engine with empties meant 300 axles of this type or 75 wagons making a total of $75 \times 8=600$ tons of tare. The train of the second engine might consist of soo loaded axles and could possibly be formed of two-axle stock of I I tons capacity; the tare weight of these vehicles is 7 tons, and, assuming they had an average load of 9 tons, the weight of the train would result as follows :-

Load: roo vehicles, 9 tons each,

$$
\begin{gathered}
\begin{array}{c}
\text { i.e., } 100 \times 9 \ldots \\
\text { Plus } 100 \text { vehicles, } 7
\end{array} \text { tons tare } \\
\begin{array}{c}
\text { each, i.e., } 100 \times 7 \\
\ldots
\end{array} \ldots=\frac{700 \text { tons of cargo }}{\ldots} \text { tons of tare } \\
\text { Total } \ldots
\end{gathered}
$$

Under the axle rating principle these trains were both considered fully loaded and, for engine user purposes, equal; yet, as has been demonstrated, the first train weighed only 600 tons of tare running on bogies, whilst the second consisted of 900 tons of load carried in 700 tons of tare running on rigid axles.

With such glaring anomalies the task of watching and measuring the economical working of locomotives was prac- 
tically impossible, and the fuel consumption records were, of course, misleading. This weakness, therefore, was the main thing aimed at as to be removed by the new system.

A start with this new method was made by the compilation of a statement setting forth the engine powers in tons of the different classes of engines over the various sections of the line. For this purpose ordinary trains were given a speed of 16 miles per hour and fast goods trains 25 miles per hour, whilst it was decided that two-thirds of the total power of the engine in tons should be considered as corresponding to the load of the vehicles and the remaining one-third as corresponding to the tare weight of the vehicles, and this basis was adopted because it represented the actual relation of the capacity of the Central Argentine Railway wagon stock to the tare weight of that stock.

It then became necessary to determine to what extent this tare weight could be increased without endangering the smooth working of the train at the speed allotted. A study was made of the results obtained in this respect by dynamometer car trials on the Canadian Pacific Railway, and these results were tested in practice by trials during a period of, approximately, one year. In these trials numerous variations of train formation were experimented with. It was obviously clear that an engine with power to haul 1,500 tons, composed of two-thirds of load and one-third of tare, could not pull 1,500 tons composed entirely of tare, but it was by no means clear, at the beginning, to what extent tare could be increased to compensate for lightly-loaded or empty wagons, and it was only after experimental runs in various places, under differing weather conditions, that it was tentatively decided that for every decrease of 20 tons in load there could be added Io tons of tare, so that on this ratio a train equivalent to $I, 500$ tons composed of $I, \infty 00$ tons of load and 500 tons of tare would be a train composed of $\mathrm{r}, 000$ tons of tare of empty vehicles.

Thus for the measuring of locomotive performance the haulage of the 1,000 tons of tare was considered equivalent to the haulage of $I, 500$ tons in the fully-loaded train, whilst similarly-following the same relation-a train of 600 tons of tare was looked upon and considered the equivalent of a 900 tons fully-loaded train.

Before the general adoption of this principle was decided upon, a modification was found necessary arising from the experimental runs which had been made, as in practice the efficient utilisation of the maximum power of the 
kocomotive had, in certain instances, to be subordinated to the length of the station sidings and cross-overs.

Repeated tests had demonstrated that, for calculation of the length of a train, it could be accepted that one ton of tare represented one metre of length, and this knowledge proved of considerable value in operating.

After this all the old train working forms were withdrawn and simple new forms substituted in their place, whilst books of simple tables were provided for the train staff to facilitate an easy appreciation as to when a train was fully loaded according to the relation of the weights of cargo and tare of which it was composed. The system was then generally put into practice, and from the train documents details were tabulated for the guidance of the operating officers.

Unfortunately, lack of appreciation by the road staff, inaccuracies in the compilation of the forms and inattention to instructions gave rise to complications, which after a while brought about the abolishment of the system and the reintroduction of the axle one, but, I am pleased to say, this change did not last for long, as train working results made such bad comparison that at a later date the tonnage system was reintroduced and has remained in force ever since with complete success.

The engine ratings have, however, been modified from time to time as experience has shown it to be necessary, brake power and bad water being two of the factors which largely affected the original ratings.

I hope the Author will not mind my mentioning what appears to me to be a rather important omission from his Paper; l refer to the time employed by the engines whilst working their trains.

We have found that the most effective measure of locomotive performance is the work it does per hour in steam, and to obtain this it is our practice to record the ton-miles of cargo, ton-miles of tare and ton-miles of gross load for each engine trip, as also the time occupied for that trip, and from these figures we extract the work performed per locomotive hour.

The careful examination of these figures has also brought about alterations in the timing of certain trains, as we found that in certain parts of the line improved results were obtained by lightening a load and quickening the speed.

This can be illustrated to you in many ways, but it would occupy time which can hardly be spared at present. How- 
ever, I would like to congratulate $\mathrm{Mr}$. Kimberley on having brought this matter forward for your consideration, and I trust that it will receive earnest attention, because-as I have before remarked-I am convinced there is still room for improvement generally in our methods in this respect.

Mr. Falconer (Central Argentine Railway): I am sorry that I have little experience of practical tonnage rating, but $i$ have had some experience of calculations in connection with this subject, and I am convinced that the formulae in general use give too wide a variety of results to be used other than in conjunction with some other practical method.

The rolling-stock used by British and American engineers for the tests upon which their well-known formulæ are based may differ a good deal from that used in this country. A few inches difference in the diameter of wagon wheels or a difference in the ratio of tare to load carried will considerably alter resistances of the whole train.

The Author gives a brief review of the method adopted by the various railways of this country for calculating their train loads, the derivation of which must be interesting.

An accurate estimation of the resistances, however, is only one-half of the equation, and for a satisfactory result the tractive effort of each class of locomotive must also be accurately determined. When this is obtained purely by calculation the weak point is the mean effective pressure, which is generally assumed between 75 per cent. and 85 per cent. of the boiler working pressure. When it is noticed that a difference of Iolbs. per square inch in the M.E.P. of a powerful locomotive may mean a difference of 200 tons behind the tender, it is evident that assumption is not good enough.

Referring to the Author's Paper in the paragraph introducing the formula for the T.F. of 2-cylinder compound locomotives, he states that the h.p. exhaust should represent the 1.p. initial pressure; the formula quoted is based on that assumption. This will rarely happen in practice, and the "drop" in pressure due to the mixture of two volumes of steam at different temperatures and pressures will vary with the design of the cylinder and receiver arrangements, and whether the engine is using superheated or saturated steam.

Failing actual tests, a check may be made and have assured M.E.P. by following the expansion of steam through the cylinders, allowing suitable diagram factors. 
While an approximate method of tonnage rating is obtained from calculation and a practical knowledge of the rolling-stock, it does not insure that the locomotives are being used to the best advantage. A more satisfactory system is the use of the dynamometer car, by which the effective tractive effort of the locomotives and the resistances peculiar to the track and rolling-stock of each individual railway may be accurately measured and convenient charts prepared.

Mr. Gabb (Chief Draughtsman, Buenos Aires Western Railway): There is one thing we found very interesting in the Paper-the question of higher loads-but I think we will have to consider power brakes and different forms of coupling; that means an important outlay and difficulty in re-design, so that looking at it all the way round it seems to me the only thing to do is to start by co-ordination between different departments.

Mr. F. D. Southgate (Assistant Traction Superintendent, Entre Rios Railway): Two important points bearing on engine rating and train resistance have not been brought out in the very interesting Paper we have just heard. These are :-

First-Che need for taking into account the increase of power which the addition of the superheater gives the locomotive. Practical experience has demonstrated that of two engines with the same tractive effort as given by the usual formula, one being a superheater, the superheater engine has a greater hauling power than the non-superheater. So far as I am aware, there is no recognised rule to take account of the superheater when working out the tractive effort.

Second-The influence of track condition on train resistance. A load which an engine would haul on good track would prove excessive on bad or indifferent track, a fact which is of great importance in a country like the Argentine. I believe that experience in the U.S.A. has been that improved track conditions have reduced the train resistance in lbs. per ton about half the former figure before the improvements were effected.

The whole subject of train resistance is a complicated one, as evidenced by the results of various tests in different parts of the world. Formulæ which give good results on one road are inadequate for another, and it only remains to study local conditions in each case and take a formula which most nearly fits in with these conditions, introducing any modification which may be necessary. 
Mr. Case (Deputy Running Superintendent, Central Argentine Railway): This subject has been presented very ably by the Author, but in respect to his remarks that proposals for new systems of train loading often meet with opposition from the operating staff, I would like, as a traction man, to set out a few practical points which must be taken into consideration in dealing with any system of train loading in this country, and which tend to make impracticable schemes for what theoretically may be perfect loading.

In respect to the advantages, for example, of the heavily loaded train, to-day we have not only to consider the work which the engine can perform, but also the hours of duty of the engineman, and since the running sheds on most railways were constructed at such distances as a man working I 2 hours could reach in a day's work, it is often a problem today to get a train through in the 1o hours 45 minutes now allowed, and trains have to run at a corresponding higher speed in order to do this, and the loads lightened accordingly.

On the whole, therefore, I am inclined to agree with Mr. Johnson's idea of a reasonably lighter train with a quick turn round of engine power.

Another point which contributes towards imperfect loading results in this country is the fact that all loaded traffic flows to the ports; thus for every five engines arriving with loaded trains it may be taken roughly that only three are required to return with empties if fully loaded trains are the rule.

It would be interesting to have the opinions of those present as to-if in such cases it is more advantageous to loading results and more economical in working to return so many of these engines with complete trains and so many light, or to return engines as quickly as possible with whatever empties are available.

Personally, I prefer the latter, but it is a practice not conducive to good average loading results.

Another point not yet touched upon is the great assistance intelligent controllers can give in reducing loads in bad weather.

Loading is naturally based on what an engine can haul economically under normal conditions, and if loads are not reduced in stormy weather, not only do engines work uneconomically, but time is lost and trains planted.

Another point upon which the opinion of those present would be interesting is in respect to the reduction of loads in 
winter. We on the Central Argentine have had the practice of reducing all loads regularly every winter: this, we are now inclined to think, has been overdoing it.

Mr. Nixon (Managing Director, Percy Grant \& Co.) : I should like to ask Mr. Johnson, in reference to his remarks as to advantages of fast light trains compared with slow heavy trains, which would require the larger number of locomotives, as some railways have to consider this point?

Mr. Johnson: It depends on the weight to be moved and other circumstances.

Mr. Nixon: Perhaps I have not made my question quite clear. Which would require the larger number of engines, the heavy slow trains or the light fast ones?

Mr. Johnson: Generally speaking, the fast trains would require the lesser number of engines.

Mr. Rea (Buenos Aires Western Railway): Another matter of great importance which has not received the attention it warrants is that of wind resistance. This is an item of consideration on railways such as the Western, which runs east and west in an open country where the prevailing winds are practically north and south. I mention this since the Author makes reference to railways which have elaborate systems for calculating the reductions of load necessary to compensate for bad weather.

If there is any member present who is on the staff of a railway on which such a system is in vogue, I am sure it would interest us all to hear from him, and perhaps the Author in his reply will furnish us with further particulars.

The Chairman: There is a point I should like to speak about before I ask the Author to reply. I think it may be taken for granted that the policy of the railways in this country will be to consolidate and improve their working in the territories they already serve rather than to be making extensions into fresh country, which was the case before the war. Under these conditions it will be imperative for the staff to do everything to increase efficiency by applying more and more English efficiency methods as the density of traffic warrants them.

To enable this to be done, accurate information must be available as to what a locomotive can do and what power it takes to move a given weight of train under continually varying conditions. Mr. Falconer has put his finger on the spot when he spoke about a dynamometer car. One should 
be available for every railway to collect accurate data, to check its regular train and locomotive performance.

Mr. Bannatyne : Re alteration for winter and summer loading, it used to be our practice to reduce the load by I 2 per cent. for the winter, but in the winter of 1914 , when the temperature remained high, we did not do it. We do not make a hard and fast rule for a particular date.

With regard to the speed of trains, in the old days we used to run at 25 kilometres, but now we run, start and stop on some sections at 29 kilometres and on others 26 .

The Southern and Western Railways have already placed an order for a dynamometer car, and when it comes out I have no doubt we shall be only too glad to lend it to Mr. Ryan.

The Author: In connection with Mr. Johnson's remarks as to the advisability of running fast light trains in preference to slow heavy trains, I wish to point out that it is a matter which is not usually decided by the running superintendent, but generally left to the traffic manager or the administration authorities, and naturally depends on the prevailing local conditions and the time which any train may be allowed to occupy any particular section.

Consequently, when the scheduled time of any train has been fixed, the locomotive engineer who is dealing with the rating of engines can then decide what train the locomotive can contend with, according to speed, curves, grade and train composition.

The proportion of 6lbs. and rolbs. per ton resistance for loaded and empty vehicles, as mentioned by Mr. Bannatyne, on the Western Railway, does not make any allowance for trains of different speeds, inasmuch as train resistance increases with speeds above ro kilometres per hour.

Mr. Bannatyne: The proportion between 6 and Io tare for empty wagons I do not take as absolutely correct figures.

The Author: As regards train speed in this country, as far as the Pacific Railway is concerned, we make allowances for increased speed, and on fast direct fruit trains between Mendoza and Buenos Aires, which are being run at the maximum speed allowed by the Director of Railways, our train loads are reduced to 800 tons, the same class of engines hauling very much heavier trains which are not scheduled as fast as the fruit trains. 
In reply to $\mathrm{Mr}$. Falconer, $r e$ the manner in which tractive cffort has been calculated, using 80 per cent. of the boiler working pressure, which has been allowed in the Paper, there is only one correct manner of obtaining the maximum tractive effort, and that is by taking the mean effective pressure in the cylinders, which must be obtained with a steam engine indicator.

In referring to the Paper, it is stated that this tractive effort can only be realised when running at slow speeds, as the capacity of the boiler is limited, and has to be considered when the speed is increased. Also, the maximum tractive effort is only required at points where the maximum grades have to be contended with. An economical percentage of cut-off can easily be obtained when running on the level, due to the grade resistances consuming such a big percentage of the coefficient of friction, consequently I do not see the force of Mr. Falconer's argument.

The question as to the method of calculating the tractive effort of compound locomotives certainly depends on the area of the cylinders, but in the Paper it is assumed that the area of the cylinders constitute proper design, for which reason, if the work done on either side of the engine is equal, which is proper practice, then the exhaust pressure of the high pressure cylinder can be assumed to represent the initial pressure of the low-pressure cylinder.

Mr. Southgate has mentioned that the tractive effort of the superheated locomotives, or the load which they haul, may be increased above the load consigned to saturated locomotives of the same dimensions.

On the Buenos Aires and Pacific, however, when we commenced superheating, the boiler pressure was reduced on all engines superheated from 175 lbs. to r6olbs. per square inch, with a subsequent reduction in the tractive effort. We have not increased our loads due to superheating, but any advantage obtained by the superheated engines is accounted for by them hauling the same load as a saturated engine with ${ }_{5} 5$ lbs. per square inch less boiler pressure.

In speaking of traffic to and from the port, we experienced a certain amount of trouble on the Pacific with our port service. The trouble was not due to the engines not being able to haul the trains, but on account of dense traffic and the difficulty in handling or controlling a heavy or long train of empties at level crossings. The loads on our 701 class engines had to be reduced to enable the drivers to have a better control of their trains at these points, principally 
252 JOURNAL OF THE INST. OF LOCO. ENGINEERS.

on account of our goods stock not being equipped with the through brake.

The Chairman: In conclusion, I would like to propose a hearty vote of thanks to the Author for his work in compiling this useful Paper. Secondly, I wish to thank Mr. Bennett for his hospitality to-day and for arranging this visit to Junin and the Pacific Railway shops; the visits to works are a very important phase of our activities. Lastly, may I express our thanks to Mr. Usher, the General Manager of the Pacific Railway, for his presence amongst us. It is entirely due to the encouragment of the General Managers of the Argentine and other South American railways that this Centre of the Institution has made such a good start. I cannot say how grateful we are to them.

This, Gentlemen, terminates the meeting. 